\title{
SIGNIFICANCE OF TOLERANCE IN REVEALED RELIGION \& INDISPENSABILITY OF INTER-FAITH DIALOGUE IN PRESENT
}

\author{
Dr. Musferah Mehfooz*, Dr. Qazi Furqan Ahmed ${ }^{* *}$ \\ The Scholar Islamic Academic Research Journal || Web: www.siarj.com || \\ P. ISSN: 2413-7480 || Vol. 4, No. 2 || July -December 2018 || P. 57-80 \\ DOI: 10.29370/siarj/issue7ar7 \\ URL: https://doi.org/10.29370/siarj/issue7ar7 \\ License: Copyright c 2017 NC-SA 4.0
}

\begin{abstract}
:
Judaism and Christianity are the revealed religions like Islam. The major common factor of this resemblance is the belief in Oneness of Allah. This belief establishes the foundations for tolerance in social and communal life through which fair justice and equality can be achieved in the society. There are important points to be noted here, that if international community can be made united and an international political body can be established and could tackle the issue of law and order. Then why the followers of Shâāì āh (revealed law) i.e. Jews, Christian and Muslims cannot be unite. Unfortunately, if this doctrine could not establish, the world cannot be achieved tolerance and harmony. These revealed religions had given the concept of religious tolerance which is substantiate by the teachings of Hazrat Ibrahim (A.S), Hazrat Musa (A.S), Hazrat Esa (A.S) and Hazrat Muhammad (SAW). The teachings of all these prophets were based on unity, justice, tolerance, peace and standard morals. The article Sheds lights the importance of peace in the world and
\end{abstract}

\footnotetext{
* Assistant Professor, Islamic Studies, Humanities Deptt, COMSATS, Lahore, Pakistan. Email: musferahmehfooz@cuilahore.edu.pk ORCID ID: https://orcid.org/0000-0002-3368-9823

** Assistant Professor, Department of Islamic Studies, University of Gujrat, Pakistan. Email: qazi.furqan@uog.edu.pk ORCID ID: https://orcid.org/0000-0003-0621-0482
} 
need to understand the real teachings of revealed laws in Bible and Qur'ān, and highlights the importance of interfaith- dialogue among Book-keepers, also analyses the life of Holy Prophet (SAW) and Caliphate Era with reference to tolerance and harmony. It is also tried to give suggestions' and recommendations for the solutions of contemporary problems of mankind.

KEYWORDS: Judaism, Christianity, Islam, Tolerance, Interfaith

$$
\text { Dialogue, Peace }
$$

\section{Introduction}

Islam is the same religion that was revealed to, preached and followed by Adam, Noah, Abraham, Moses, Jesus and all other prophets of $\operatorname{God}(A s)$.Prophet Muhammad (Peace be upon him) was the final link in the chain of divine messengers. Islam therefore, is the continuity of divine guidance since the beginning of the human history on earth, not a new religion founded by Prophet Muhammad (Peace be upon him) in seventh century. Further explain this doctrine in these words:

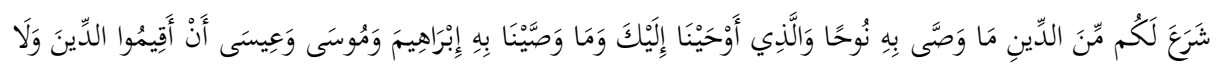

$$
\begin{aligned}
& \text { تَتَفَرَقُقُوا فِيهِ }
\end{aligned}
$$

In matters of faith, $\mathrm{He}$ has ordained for you that which $\mathrm{He}$ had enjoined upon Noah - and into which We gave thee [O Muhammad] insight through revelation as well as that which We had enjoined upon Abraham, and Moses, and Jesus: Steadfastly uphold the [true] faith, and do not break up your unity therein. ${ }^{1}$

In Holy Qur'ān the Eighteen Times the words "يايها الناس" are used to address the whole humanity without regard of their cast, color,

\footnotetext{
${ }^{1}$ Al- Qur'ān, 42:13
} 
creed and religion. The Holy Qur'ān addresses all the human beings including Muslims and non-Muslims and lifts the curtain from the secrets of this universe.

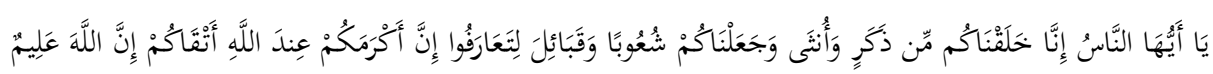

O men! Behold, We have created you all out of a male and a female, and have made you into nations and tribes, so that you might come to know one another. Verily, the noblest of you in the sight of God is the one who is most deeply conscious of Him. Behold, God is all-knowing, all-aware. $^{2}$

Islam is a universal religion. As the Prophet Hazrat Muhammad (SAW) said:

$$
\text { الخلقُ كُلُهم عِيالُ اللهّ عزَّ وجلَّ، فأَحَبُُّ خلقِه إليه أنفعُهم لعِيالِه" }
$$

(The whole humanity is created and supervised by Allah and most beloved among them is he, who is most beneficial for mankind.

In early prophetic era when Emperor of Persia Khusraw Parvēz had conquered the Byzantine (Eastern Roman), they had treated them inhumanly and had showed extreme brutality to perish the Christianity, killed more than a Hundred thousand Christians, demolish the temples and monasteries and built the fire temples everywhere. Christians were forced to worship the fire rather than Christ. During these circumstances when Harqal, the King of Rome had tried to do reconciliation with Emperor of Persia Khusraw Parvēz, Then Khusraw Parvēz had replied which indicated his non tolerable thought,

${ }^{2}$ Al- Qur'ān, 49:13

${ }^{3}$ Al-Tabrani, al-Muajam al-kabeer, Hadith No:10033 
"No, I want Harqal the King of Rome, imprisoned in chains under my throne, I will not reconciliate until he denied the Christianity and embraced the religion of Persian empire." 4

There is another historical facts about Jews are discussed in following words, that They have forbidden the Christians entries in their synagogues. The ouster of Christians from the Jewish places of worship commenced from Intaqia and gradually spread towards other areas of the sultanate. ${ }^{5}$

According to eminent Muslim scholar Shah Wali- ullah: "Also a prime factor of advent of the Holy Prophet (SAW) was to stop the two tyrannous rules of the day (Persia and Byzantine (Eastern Roman) and the others like them. Economic in equilibrium reached its heights those days and a limited well off class were doing overpower the public on account of their capital and possession. Thus in this case, they forgot Allah (and felt no scruples). According to the burden of heavy taxes, people were compelled to spend their lives like oxen and donkeys". 6

Because in contrast, when we study the life of our prophet (SAW, we find endurance and toleration towards non-Muslims and his opponents throughout his life. He never tried to compelled someone to accept Islam and nor misbehaved any non-Muslim because of his doctrine but always showed far-sightedness and elegance of manner.

\footnotetext{
${ }^{4}$ Shibli Naumani, Seert-ul-Nabi, Dar al-asahat,Krachi, 1985, Vol:2, P: 97

${ }^{5}$ Siddiqui, Mazhar-ud-Din, Mazahib-e-Aalam, (Lahore, Idara Saqafat-eIslamiya, 1956), p.150

${ }^{6}$ Shah Waliullah . Hujjat Allah Al-Balighah, Egypt, Dar al Nashr, (ND). 1, P105
} 
Jews and Christians have strong belief in God. Therefore Prophet (SAW) made this doctrine of Tawhid ( oneness of Allah) as a source of unity because, through this plate form all the followers of revealed religion could be unite, and Prophet (SAW) had tried to avoid any kind of discussion other than God for the achievement of peace and harmony among Book-keepers. This indicates the zeal for alliance among the Bookkeepers of holy prophet (SAW) and also it was the source for existence of peace because prophet (SAW) was declared the blessing for whole humanity.

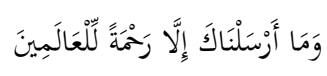

And [thus, O Prophet,] We have sent thee as [an evidence of Our] grace towards all the worlds. ${ }^{7}$

Therefore all the nations were decided to be addressed by the prophet (SAW).Allah has clearly convey his message that all the humanity is one nation.

In his last sermon Hajja Tul-Wadae (The last pilgrimage), the Prophet (SAW) said, "O people! Lo your Lord is One, no Arab is superior to a non-Arab and no non-Arab is superior to an Arab. No black is better than a red and no red is better than a black. Then only criterion for superiority and honor is piety". 8 According to these teachings, a true global brotherhood could establish if the Muslims would eliminate all the

${ }^{7}$ Al- Qur'ān, 21-107

${ }^{8}$ Ahmad bin Hanbal, Al-Musnad, Beirut, Al-Maktab Al-Islami, (1938). 5, P- 411. 
discriminations. This will away from all sorts of favoritism, inequity and prejudice. Mutual love, peace and prosperity will be all around.

There is another example of Charter of Medina, and according to this constitution, Jews of Medina were considered an important part of the community of Madina, although they had overruled the agreement, but In so doing, they were also existed among the Muslims in Medina. ${ }^{9}$

For example, Once a delegation of Christian religious scholars and leaders of Najran had visited to Medina and prophet (SAW) had arranged their stay in Masjid Nabwi, served them noble hospitality and offered them Islam, which they did not accept, after a few moments they started to offer their prayers according to their doctrine and companions of Prophet (SAW) tried to stop them but Prophet (SAW) allowed them to do so and they offered their parayer by facing towards East (Aqsa Mosque). ${ }^{10}$

Another example from the life of Prophet (SAW) is, when he sent some cavalry towards Najd and they brought a man, who was called Thumama bin Uthal. They fastened him to one of the pillars of the Mosque. The Prophet went to him and said, "What have you got, O Thumama?" He replied," I have got a good thought, O Muhammad! If you should kill me, you would kill a person who has already killed somebody, and if you should set me free, you would do a favor to one who is grateful, and if you want property, then ask me whatever wealth you want." But after three day he had inspired from good morals of Prophet (SAW), and when he released, he (i.e. Thumama) went to a garden of date-palm trees near to the Mosque, took a bath and then entered the Mosque and said, "I

9 Al-Seerah Al-Nabawiyah, Ibn Hisham, Maktabah Mustafa al-Halbi, Cairo, $1955,1 / 501$

${ }^{10}$ Shibli Naumani, Seert-ul-Nabi, Dar al-asahat,Krachi, 1985, Vol:2, P: 221 
testify that None has the right to be worshipped except Allah, and also testify that Muhammad is His Apostle! By Allah, O Muhammad! most disliked face by me was yours, but now most beloved face for me is your face. By Allah, there was no religion most disliked by me than yours, but now it is the most beloved religion to me. By Allah, there was no town most disliked by me than your town, but now it is the most beloved town to me. Your cavalry arrested me (at the time) when I was intending to perform the "Umra. And now what do you think?" The Prophet (SAW) gave him good tidings (congratulated him) and ordered him to perform the 'Ūmrā. So when he came to Mecca, someone said to him, "You have become a Sabian?" Thumama replied, "No! By Allah, I have embraced Islam with Muhammad, Apostle of Allah. No, by Allah! Not a single grain of wheat will come to you from Yāmāmāh unless the Prophet gives his permission." ${ }^{11}$ It indicates tolerance and his regard for bond of kinship that after immense torture and opposition of Maccans, Prophet (SAW) allowed them wheat.

It was the teachings of Prophet (SAW), which was followed by his companions, it is reported that, Sahl canister Hunaif and Qais container Sa'd were sitting in the city of Al-Qadisiya. A funeral procession go before them and they held up. They were informed that funeral procession was of one of the occupants of the land i.e. of a non-adherent, under the security of Muslims. They stated, "A funeral procession go before the Prophet (SAW) and he stood up. When he was told that it was the coffin of a Jew, he said,

${ }^{11}$ Sahih al-Bukhari, Military Expeditions led by the Prophet (pbuh) (AlMaghaazi) ,Chapter: The delegation of Banu Hanifa, 4372 
"Is it not a living being (soul)?" 12

A Jewish boy used to serve the Prophet (SAW) and became ill. The Prophet (SAW) went to pay him a visit and said to him, "Embrace Islam," and he did embrace Islam. ${ }^{13}$

A Jew whose face had been slapped (by someone), came to the Prophet (SAW)and said, "O Muhammad! A man from your Ansari companions slapped me. "The Prophet (SAW)said, "Call him". They called him and the Prophet (SAW) asked him, "Why did you slap his face?" He said, "O Allah's Messenger (SAW)! While I was passing by the Jews, I heard him saying, 'By Him Who chose Moses above all the human beings.' I said (protestingly), 'Even above Muhammad?' So I became furious and slapped him."

The Holy Prophet (S.A.W) has taught tolerance and has practiced it as well.

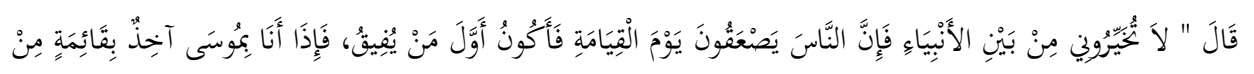

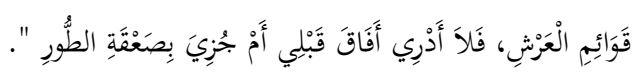

The Prophet (SAW)said, "Do not give me preference to other prophets, for the people will become unconscious on the Day of Resurrection and I will be the first to gain conscious, and behold, I will Find Moses holding one of the pillars of the Throne (of Allah). Then I will not know whether he has become conscious before me or he has been

\footnotetext{
${ }^{12}$ Muhammad bin Isma'il al-Bukhari,Sahih al-Bukhari 1312, 1313, Funerals (AlJanaa'iz) ,Chapter: Standing for the funeral procession of a jew

${ }^{13}$ Sahih al-Bukhari, Chapter: Sickness is expiation for sins ,Chapter: To vist a Mushrik, Hadith No: 5657
} 
exempted because of his unconsciousness at the mountain (during his worldly life) which he received." ${ }^{14}$

The Prophet (SAW)said, "Do not prefer some prophets to others." 15

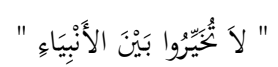

Another place Allah's Messenger (SAW)said,

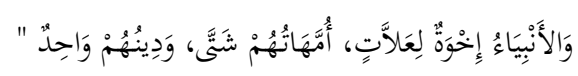

The prophets are paternal brothers; their mothers are different, but their religion is one." 16

In the event where no ruling could be found in the Qur'àn on a religious or customary matter, the Muslims assimilated the ways of the Jews and Christians and followed their example. For instance, the Muslims followed the hair-style of the Jews in preference to that of the pagan Arabs, ${ }^{17}$ and faced Jerusalem in their prayers for a period of about 16 months. ${ }^{18}$ Also, when the Prophet knew that the ahl al-kitab, especially the Jews, observed fasting on the day of 'Ashura (tenth of Muharram), he

${ }^{14}$ Sahih al-Bukhari, Blood Money (Ad-Diyat),Chapter: If a Muslim, being furious slaps a Jew, Hadith No: 6917

${ }^{15}$ Ibid, 6916

${ }^{16}$ Sahih al-Bukhari, Book of Prophets,Chapter: The Statement of Allah Taa'la: "And mention in the Book, the story of Maryam..." Hadith No: 3443

${ }^{17}$ The pagans of Arabia used to part their hair when they combed, whereas the Jews did not, and the Muslims followed the latter. Later when relations between the Jews and Muslims took a negative turn, the Muslims differentiated themselves in another respect: while the Jews grew their moustache and shaved their beard, the Muslims did the opposite by shaving their moustache and keeping their beards. Mohammad Hashim Kamali,Islam and Judaism: Juridical and Theological Perspectives, Article presented at "On Dialogue between Islam and Judaism: "others" and "Ours" in Rethinking" at Niijima Kaikan, Kyoto, Japan on July 2, 2009.

${ }^{18}$ Sahih al-Bukhari, Book of Fasting, Chapter: Observing Saum (fast) on the day of 'Ashura. Hadith No: 2002 
ordered the Muslims to fast on that day. However, the Prophet (SAW) later instructed the Muslims to fast on the 9th and tenth of Muharram to differentiate themselves from the Jews. The Prophet (SAW) used to stand up whenever he saw a Jewish funeral procession.

The life of the Holy Prophet (SAW) is decorated with the examples of tolerance and kind heartedness. After attaining Prophet hood, numerous blames were leveled against the Holy Prophet (SAW), But the Holy Prophet (SAW) remained calm and patient along with his companions in the face of these odds. He captivated the hearts of the people due to his forgiving temperament in Mecca as well as in Madina.

\section{Religious Tolerance during Caliphate Era}

During the era of second caliph of Islam, the General of Christian army of Mery had wrote a letter to Shamoon of Persia and confessed in his writings, that Arabs are blessed a great dynasty by God do not attack on Christianity, even they are our supporters, respect our God and do regard our saints, give donations to our churches and monasteries. No Muslim either he is ruler, officer or an ordinary Muslim citizen is allowed to capture the property of any non-Muslim illegally. ${ }^{19}$

And second caliph made no distinction for social justice among Muslims and non-Muslims. If a Muslim has committed a murder of a zimi (non-Muslim) ${ }^{20}$ he was also murdered in retaliation and if any Muslim had harm the property of non-Muslim was bounded to pay the ransom, even a

\footnotetext{
${ }^{19}$ Sayyed Amir Ali, Rooh-ul- Islam, (karachi: Dār al-asha 'at ), P.462

${ }^{20}$ A non-Muslim who lives in Muslim country and pay tex (jaziah) to Government
} 
Muslim was answerable in case of harsh words or disrespect of nonMuslim. $^{21}$

Not only according to Islamic law Muslims and Zimi (nonMuslim) have equal rights in the state, but also consider equal in social status. "So the fourth caliph of Islam said, Their blood is just like us". ${ }^{22}$

During the whole period of Caliphate the same religious tolerance

had followed with non-Muslims which were practiced by the prophet (SAW). They had given the same rights and facilities which they had already avail during the period of Prophe $\mathrm{t}(\mathrm{SAW})$.Hazrat Abu Bakar $(R A)$ and Hazrat $\operatorname{Umar}(R A)$ had renewal the same constitute of Christians of Najran, which was settled down by Prophet(SAW) with them. ${ }^{23}$

Even we will not demolish those specific buildings and castles in which they take refuge during the attack of their enemies. Their rituals like ringing bells and blow a conch (at divine worship to summon the congregation ) are not forbidden in any city of Muslim empire, also on their religious festivals they were allowed for procession of Holy Trinity. ${ }^{24}$

Another important Example is of a Christian man, who came from Egypt to 'Umar ibn Al-Khattab and said, "O leader of the believers, I seek refuge in you from injustice!" 'Umar replied, "You have sought someone willing." The man said, "I competed with the son of Amr ibn Al-'As and I won, but he started striking me with a whip and saying: I am the son of the dignified!" Upon this, 'Umar wrote to Amr ordering him to travel to him

${ }^{21}$ Shah Moen-ul-Din Nadvi, Tarekh Tamadun Islami, , Subhan Publications , Lahore, Vol:1, P: 189

${ }^{22}$ Sayyed Amir Ali, Rooh-ul- Islam, (karachi: Dār al-asha 'at ), P.462

${ }^{23}$ Shibli Naumani, Seert-ul-Nabi, Dar al-asahat,Krachi, 1985, Vol:2, P: 382

${ }^{24}$ Abu Yusuf Yaqub ibn Abd Al-Haqq., Kitab al-Kharaj, (Beirut: Dār al-al kutub al- ilmmiyya ,1999) p.72-73 
with his son. He came with his son and 'Umar said, "Where is the Egyptian?" He gave him the whip and told him to strike the son of Amr. The man started striking him while "Umar was saying, "Strike the son of the illiterates!" Anas said, "By Allah, the man struck him and we loved his striking, and he did not stop until we wished he stopped." Then 'Umar said to the Egyptian, "Direct it to Amr." The Egyptian said, "O leader of the believers, it was only his son who struck me and I have settled the score." 'Umar said to Amr, "Since when did you enslave the people though they were born from their mothers in freedom?" Amr said, "O leader of the believers, I did not know about this and he did not tell me.,"25

Not only the western inhabitants, one of the most ancient Egyptian civilizations had warmly welcomed the Muslim civilization, Because Muslim civilization had conquered their hearts forever due to its nature of betterment and welfare. So it is notable for the book-keepers that individual can subdue the hearts of others trough love, brotherhood and peace rather than wars, battles, racial prides and prejudices. Because these emotions and actions do not promote except hate, enmity and revenge in nations of world and in return our next generation harvest the crop of hate and be agitated and troubled.

\section{Teachings of The Holy Bible about Religious Tolerance}

Throughout the history religious narrow mindedness and intolerance had existed In the Jews for other nations, and mingling with other nations and religions is specifically avoided. But when we study

\footnotetext{
25 Ibn Al-Qayyim, I 'alam Al-Muwaqqi in `An Rabbil-`Aalamin, DarulKutub Al-`Ilmiyyah 1991, vol.2, p.124.
} 
their religious book like Bible, Talmud and other religious literature, the situation is opposite. Their religious scholars had taught kindness and tolerance, although there is available few literature, which is not in favor of non-Jews, but most of their Rabbi's had preached kindness and love with humanity, for example, Rabbi Mayor's statement is given in the following lines:

"The aim of Judaism is to unite humanity and not to separate them. Everyone will have to be humble, tolerant not only with the people of his own religion but with all". ${ }^{26}$

In the Book of Malachi, it is stated:

Are we not all children of the same Father? Are we not all created by the same God? Then why do we betray each other, violating the covenant of our ancestors? ${ }^{27}$

According to Judaism, love of God is the first duty for man, for when a man is possessed by that love he will seek to do the good even at the price of life itself. It is man's duty to keep his soul pure, for, the soul is a gift from God. ${ }^{28}$ But the commandments of love is just absolute we must overcome the psychosis of hatred, break down all social prejudices and shatter the bonds of selfishness. ${ }^{29}$

New Testament points out tolerance, equality, brotherhood and righteousness which are contained in the teaching of Hazrat Esa (A.S). The teachings of Hazrat Esa (A.S) reflect compromise and love among the

${ }^{26}$ H.Polono, Talmud, (Translation: Stephan Bashir), (Gojranwala, Maktaba Anaweem Pakistan, 2003),

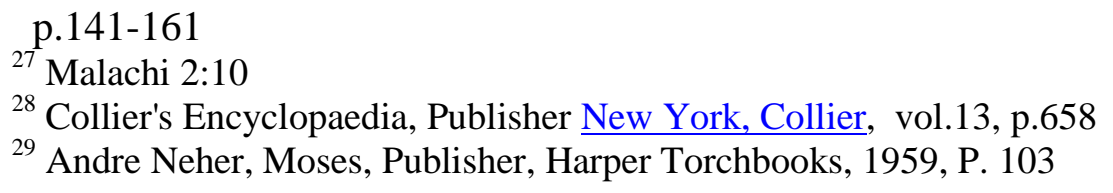


people. Hazrat Esa (A.S) instructed his companions to follow these things. It is said in Gospel of Matthew:

"Those people are the blessed who make compromise because they are the sons of God" ${ }^{30}$ Hazrat Esa (A.S) preached love and removed the worries of the people and healed their wounds. His message was packed with love and tolerance. One of his aims in this world was to throw away hatred, enmity and malice from the hearts of Bani Israil. He wanted to disseminate tolerance among those people who could not tolerate one another. For this purpose he again and again addressed his companions in order to reform them. His teachings are based on tolerance and grand manners.

According to the verses of Gospel of Matthew, God has ordered the Christians through Hazrat Esa (A.S): "Do not find faults in others so that others may not seek faults in you. The measure you use for others will be used for your measurement. Why do you perceive your brother's minor fault while overlooking you own blunders". 31

The sacred book of the Christians Gospel of Matthew has always instructed the people to develop love among the members of society even when other people are friends or foes. It has guided the Christians to avoid hatred, prejudice and harshness in manners. Hazrat Esa (A.S) has imparted the same teachings that the people should not blame one another on their defects and they should have the attitude of forgiveness and passions. He wants love and brotherhood in the lives of his followers. Life is granted

30 Matthew 5:9

31 Matthew 7:1-2 
once in this world and it should be led in such a fashion that other people may not get tired of us.

Hazrat Esa (A.S) addresses his followers in the following words:

"Tolerate one another showing complete passions and love and try to make spiritually strong link by the help of compromise. You should love your enemies, do him good and give him loan without any disappointment so that you should be paid back heavily". ${ }^{32}$

Hazrat Esa (A.S) As knew this thing that the people will turn against him as soon as he will preach them the words of Allah that is why he advised his companions to bear torture with smiling face and not to retaliate against the people who do injustice.

It is said in New Testament: "When the people will curse you and will tease you and will commit injustices against you, all for my sake, you deserve congratulations but I point it out to you that whoever shows anger for his brother, he will deserve punishment, whoever declares his brother lunatic he will deserve harsher punishment and whoever deems his brother stupid and foolish he will deserve tortures of hell. I say to you that don't retaliate against the deeds of naughty people and if any one of those strike you in the right cheek, offer him your left one and if any deprives you of your minor belonging give him your major one as well and if any one takes you for a long distance without any purpose, keep his company for the longer distance and if any one requests you something, place it at his disposal immediately and if anyone wants loan, do not disappoint him". 33

\footnotetext{
${ }^{32}$ ibid, Verse 11: 31

${ }^{33}$ ibid, Verses 39-42
} 


\section{Reason for Religious Fanaticism and Factionalism}

Jews have firmly faith in self-created doctrine that they are the "chosen ones" all the other creations are lesser in status. This belief is a huge hindrance to bring closer to other nations. Qur'ān has mentioned their doctrine in these words:

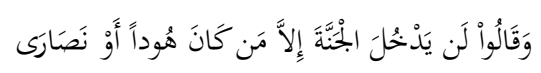

AND THEY claim, "None shall ever enter paradise unless he be a Jew" -

or, "a Christian". ${ }^{34}$

This way of thinking also depicts in the nature of Zionism by the protocols, For Example

The words goyim and gentile mean non-Jews ${ }^{35}$. The word is used everywhere in protocols, where needed for non-Jewish people. Because it represents hate and loathing of Jews for them. The hatred emotions against goyim have becomes the part of their literature, so this "doctrine" becomes the part of their spirits as well.

It is mentioned in Psalm 109:18 that goyim used to wear cursed garments and thus this curse entered into their body like water and into their bones like oil. So Jews neither change their mentality which they are receiving from generations nor do they want to leave false notion of their pride, now only a miracle from God can change their mentality and way of

\footnotetext{
${ }_{35}^{34}$ Al- Qur'ān, $2: 111$
}

35 . $\quad$ http://dictionary.reference.com/browse/goyim?s=t; http://dictionary.reference.com/browse/gentile?s=t Retrieved 8 April, 2012 
thinking for "goyim"36. The following quotations from protocols prove that it is the part of Zionist nature to consider and treat the non-Jews as animals and beasts:

The GOYIM are a flock of sheep, and we are their wolves. ${ }^{37}$ As a brute beast lets out its young in search of prey, so do the GOYIM ${ }^{38}$.

Such kind of prejudice are harmful for human welfare and betterment, and made the nation enemy of other nation. Beside this also becomes the reason of wars, the history is evident that these kinds of emotions were the causes of destruction, loss of human lives, crops and animals etc. So these instincts transform the man into selfish mean and narrow minded person.

When Muslims conquered the eastern and the western part of Europe, the Christian population of these areas had felt that Muslim conquerors had showed the same brotherhood and equality, which is mentioned in Bible. Consequently they found maximum harmony between Christianity and Islam and the large number of Christians had embraced Islam. In another verse $Q u r$ 'ân has mentioned the Jewish doctrine:

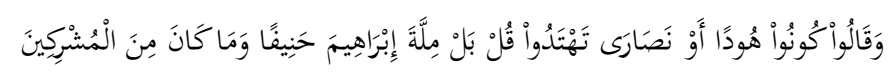

AND THEY say, "Be Jews" - or, "Christians" - "and you shall be on the right path." Say: "Nay, but [ours is] the creed of Abraham, who turned away from all that is false, and was not of those who ascribe divinity to aught beside God." ${ }^{39}$

36 Martin Luther, On the Jews and Their Lies, Published by Liberty Bell Publications, 2004, Binding: Paperback.P.47

${ }^{37}$ Protocol 11

${ }^{38}$ Protocol 15

${ }^{39}$ Al- Qur'ān, 2:135 
Therefore Allah has advise to the Book-keepers, that should strictly follow the commandments of their given books in Torat and Injeel, because its teachings will prove the truth of Qur'ān, and will become the real source of peace, safety and security of humanity, also they will find the same reality and guidance which is given in Qur'ān, because Qur'ān did not present any new or different message, it interprets the same universal message given to Hazrat Adam(AS) to Hazrat Esa(AS) . So it stated in the following verse in these words:

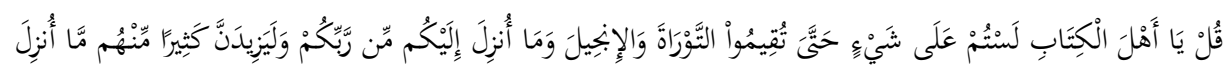

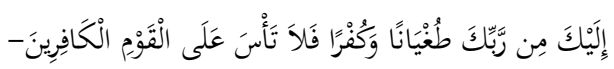

Say: "O followers of the Bible! You have no valid ground for your beliefs -unless you [truly] observe the Torah and the Gospel, and all that has been bestowed from on high upon you by your Sustainer!" Yet all that has been bestowed from on high upon thee [O Prophet] by thy Sustainer is bound to make many of them yet more stubborn in their overweening arrogance and in their denial of the truth. But sorrow not over people who deny the truth: ${ }^{40}$

And also it is mentioned that whole were single community, and the purpose of revealed books and prophets were to abrogate the contradictions which were created and disseminated by their followers and next generations,

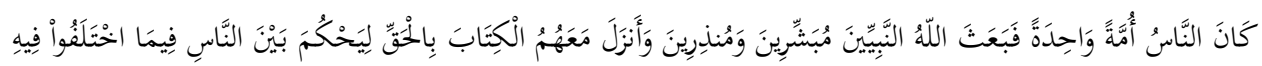

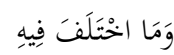

${ }^{40}$ Al- Qur'ān, 5:68 
ALL MANKIND were once one single community; [then they began to differ - ] whereupon God raised up the prophets as heralds of glad tidings and as warners, and through them bestowed revelation from on high, setting forth the truth, so that it might decide between people with regard to all on which they had come to hold divergent views. ${ }^{41}$

It is very important for Jews to adopt tolerance and to spread love in the society for the peace in the universe and for acting upon the teachings of Old Testament and Talmud. Both their religious books give lessons of human respect, love and service of humanity. If the Jews act upon Old Testament and Talmud, they will easily mix up with the general public and they will breed sympathy and love in their own minds and can create tolerance at the international level. Only then the world can become a cradle of peace for its residence.

\section{Objectives and Intentions of interfaith dialogue}

The Dalai Lama once argued that there will be "No peace among the nations without peace among the religions. No peace among the religions without dialogue among the religions". ${ }^{4}$

Dialogue, aims to learn more about spirit of truth, pure love and respect. Many examples are found in different nations like, Egyptian, ancient Greek, Indian and Arab societies. Although there are few basic differences of among different religions but some common elements are

\footnotetext{
${ }^{41}$ Al- Qur'ān, 2:213

${ }^{42}$ Linda Groff. "Intercultural Communication, Interreligious Dialogue, and Peace." Futures: The

Journal of Forecasting, Planning and Policy 34 (2002): 701-16.
} 
found, which are needed to be discussed like, peace and conflict matters, humanity issues etc. Interfaith dialogue are very effective to inspire mutual respect and to avoid from communal riots, and also a source of peaceful co-existence of the beliefs of world religions.

The Holy Qur'an says: "O People of the Book, let us come to a common statement/word (kalimatin sawa'in) between us and you..."

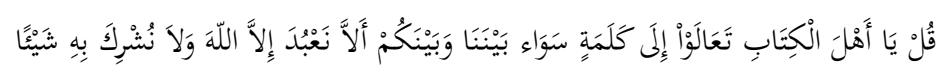

Say: "O followers of earlier revelation! Come unto that tenet which we and you hold in common: that we shall worship none but God, and that we shall not ascribe divinity to aught beside Him, ${ }^{43}$

Many Muslim thinkers had described the method and manners of dialogue, for the existence of peace and harmony among Book-keepers, which are following:

- The Dialogue should be in mild Tone and must be based on wisdom and sincerity.

- It should be held in Friendly environment, and intention behind it to get closer to the opponent.

- The Dialogue should be based on the rule of common regard and ought not contain any sort of damaging and insulting dialect.

- Blunt languages and harsh words will be avoided, and let not to intercede the unpleasant situation.

${ }^{43}$ Al-Qur'ān, 3:64 
- The dialogue holders should forbear the comments and views of opponents very open heartedly to achieve the practical solution of the matter.

- Positive thoughts, comments, views and suggestions etc, should acknowledge and recognized by the both side.

- Discussion should proceed logically and with positive arguments. Dialogue should not overrule the justice and equality.

- Bitter experiences and incidents should not share during dialogue proceeding.

- Patience and tolerance is the fundamental key of Dialogue. Try to inflict own point of view upon other and avoid the flexibility can violate the dialogue process.

- The main effort during the Dialogue should be to bring the both parties on a same platform, and avoid to blamed for the evil deeds to any one specific party.

A prominent Jewish academic, Daniel Barenboim, recipient of the Wolf Prize that honored outstanding individuals that worked "in the interest of mankind and friendly relations among nations" said in his acceptance speech in May 2004 that the state of Israel should be established on the standards of flexibility, equity and peace, guided by the dreams of the prophets of Israel. Barenboim added: Is there any sense in the independence of one at the expense of the fundamental rights of the other? Can the Jewish people whose history is a record of suffering and 
relentless persecution allow themselves to be indifferent to the rights and suffering of a neighboring people. ${ }^{44}$

In Christianity there are additionally contrasts between the Catholics and the Protestants and with other groups within the faith. In this way, unmistakably no culture or religion is without contrasts, however they should be managed through a procedure of discourse so peace can win. The essential discourse process would start by tuning in to everyone's grievances and contrasts and after that going to an accord. ${ }^{45}$ Holy Qur'ān guides in these words:

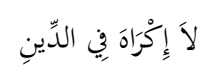

THERE SHALL BE no coercion in matters of faith. ${ }^{46}$

Also states to avoid any kind of conflict among the people of contrast religion:

$$
\text { لَكُمْ دِينُكُمْ وَِلِيَ دِينِ }
$$

Unto you, your moral law, and unto me, mine!"47

Above mentioned Qur'ānic verses instruct the Muslims very clearly on the need to be just in relation with other faiths and to not to impose their values on any culture or ideology, because there is no compulsion in Islam. Most of the problems in the present world arise from issues related to minority rights which lead to major conflicts in most countries. For instance, in Christian ruled social orders, for example,

\footnotetext{
${ }^{44}$ Daniel Barenheim "On Israel," http://www.thenation.com/doc.mhtml?1=20040607\&s=baron boim

${ }_{45}$ Ahmet Kurucan, and Mustafa Kasim Erol. Dialogue in Islam, Qur'an, Sunnah, History. London:

Dialogue Society, 1999, pp. 12-125.

${ }^{46} \mathrm{Al}$ - Qur'ān 2:256

${ }^{47}$ Al- Qur'ān, 109:6
} 
France, they have forced a decide that no woman can wear the veil despite this being a right of Muslim women. ${ }^{48}$

The common ideals of each religion can create many avenues for peace. As such, the civilizational dialogue project for world religions is one of the best methods to reach peace and harmony. It has been seen all through history that a genuine religious individual can never be an issue for alternate religious groups. A true Muslim could never be an issue for his neighbors or for any individual in the event that he truly comprehends the Holy Qur'àn and the Sunnah of Prophet Mohammed (SAW). ${ }^{49}$ Presently communication and co-operation between religions make an essential contribution to the eradication of religious fanaticism.

If religious leaders adopt moderate approaches when delivering their speeches, the mind-set of those in religious conflict can be changed. Religious preachers and pioneers can without much of a stretch educate peaceful lessons to their groups; and these endeavors should be done at each level. The balance of religious pioneers at last influences the control of religious believers at large, automatically creating new avenues of peace and compatibility within society. ${ }^{50}$ and specifically the co-operation in finding solutions to the contemporary problems of mankind, will assist in peaceful coexistence and common understanding.

48 Hilal Wani \& et.l ,An Islamic Perspective in Managing Religious Diversity ,Religions 2015, 6, 642-656; doi:10.3390/rel6020642

${ }^{49}$ Azizan Baharuddin, Raihanah Abdullah, and Lee Wei Chang. "Dialogue of Civilisation: An

Islamic Perspective.” Journal of Dharma 34 (2009): 301-18.

${ }^{50}$ Hilal Wani \& et.l ,An Islamic Perspective in Managing Religious Diversity ,Religions 2015, 6, 642-656; doi:10.3390/rel6020642 


\section{Conclusion}

The history of Islam is packed with the events of tolerance, forbearance and broad mindedness. It is Islamic trend that it throws to the winds all the differences between religions, sects, casts and has granted humanity a code of life which treats all human beings on the same footing. No one is superior or supreme. There is no room for regional and racial differences. The teachings of the all holy prophets (A.S) carried the concept of revealed tolerance but it was not exercised as it was demanded by sacred Text. Therefore, it has become the main reason to eliminate the religious tolerance and this has affected the peace in the world very badly. Because the concept of religious tolerance is very clear and practical in revealed books, and fulfills the need of all the ages. Therefore it is needed that Book-keepers should present the practical examples of this tolerance, so the people of other religions will come to know the idea of tolerance taught by Bible and Qur'ān.

At the end, I will repeat the verse of the Book of Malachi, which is the conclusion of this debate:

Are we not all children of the same Father? Are we not all created by the same God? Then why do we betray each other, violating the covenant of our ancestors? ${ }^{51}$

\section{@()(0)}

This work is licensed under a Creative Commons Attribution-NonCommercial-ShareAlike 4.0 International (CC BY-NC-SA 4.0)

\footnotetext{
${ }^{51}$ Malachi 2:10
} 